\title{
BIBLIOGRAPHIES
}

\section{Recent Books on Syriac Topics}

\section{SEBASTIAN P. BROCK, UNIVERSITY OF OXFORD}

\section{Grigory Kessel, Philipps-Universität MARBURG}

The present listing continues on from previous annual listings in the first number of Hugoye each year from 1998 onwards. Once again it should be noted that reprints are not included (for a number of important ones, see http://www.gorgiaspress.com). For the recent Russian titles see a bibliography of Kessel and Seleznyov in the same issue of the journal.

2009

J. Cheeran, The Indian Orthodox Church of St Thomas, AD 52 - 2009 (Kottayam: Kottackal Publishers).

\section{1}

I. Abī Habīb al-Anțūnī, Mār Ya'qūb al-Surūjì. Darb al-khalās min Ádam ilā Nüh: al-maqälät 147, 148, 149, 150, 108 [Mar Jacob of Serugh. The Path to Salvation from Adam to Noab: Homilies 147, 148, 149, 150, 108] (Sources Syriaques 5; Antélias: Centre d'Études et de Recherches Orientales; Université des Pères Antonins). [Arabic transl.]

Mar Aprem (Mooken) (ed.), Assyrian Manuscripts in India (Thrissur: Mar Narsai Press).

P. Castellana, Eremiti e cenobiti siriani. Tra storia e geografia (Monographiae 19; Milano: Edizioni Terra Santa).

P. Castellana, Trentacinque anni di ricerche nella Syria christiana. Scritti 1970-2005 (Teramo: Edizioni D’Errico). 
M.S. Cheriyathottam, The Magnificence of the Southists. Articles on the Knanaya Heritance (Kalpetta, Wayanad: C.O. Mathew Foundation). [rohan.mathew7@gmail.com].

J.P. Deschler, Word and Meaning. A Glossary in Liturgy and Iconography with special reference to the Theology of the Eastern Churches (Moran Etho 31; Kottayam: SEERI).

M.P. George, West Syriac Musical Tradition of the Beth Gazo in India, with music notation (Moran Etho 32; Kottayam: SEERI).

J. Mathew, Structure and theology of East Syriac Qurbana according to Gabriel Qatraya. A liturgical and theological analysis of Gabriel Qatraya's commentary on the office of the mysteries (Oriental Institute of Religious Studies 368; Kottayam: Oriental Institute of Religious Studies).

M.K. Thomas, The Way of St Thomas. A Brief History of Malankara Orthodox Syrian Church (Kottayam: Malankara Orthodox Church Publications).

2013

I. Abī Habīb al-Anțūnī, Al-kähin 'inda al-äbā' al-suryān [A Priest according to the Syriac Fathers] (Sources Syriaques 6; Antélias: Centre d'Études et de Recherches Orientales).

H. Armbruster, Keeping the Faith: Syriac Christian Diasporas (Sean Kingston Publishing, UK).

E.I. El-Badawi, The Quran and the Aramaic Gospel Traditions (New York - London: Routledge).

G.L. Carrega, La Vetus Syra del vangelo di Luca (Analecta biblica 201; Roma: G\&B Press).

A.M. Ceriani (ed.) \& E. Vergani, A Facsimile Edition of the Peshitto Old Testament Based on Codex Ambrosianus (7a1) (Piscataway, NJ; Gorgias Press). 
R. Duval, Syriac Literature (Gorgias Eastern Christian Studies 35; Piscataway, NJ: Gorgias Press). [ET of 1907 French edition].

A. Dilek, Antakya ve Tüm Doğu Süryani Ortodoks Patrikligi. Taribsel Gelisimi ve Günümüzdeki Durumu / Syriac Orthodox Patriarchate of Antioch and all the East. Historical Development and Current Status (İstanbul: İstanbul Üniversitesi).

B. Faghālī (P. Feghali), Injìl Mattā fì turāt al-suryānì (Bayrūt).

P. Feghali (ed.), L'Ancien Testament Syriaque : Le Pentatenque : La Peshitta: interlinéaire Syriaque - Arabe / The Old Testament Syriac: the Pentateuchus : the Peshitta : interlinear Syriac - Arabic / Das Neue Testament auf Syrisch : das Pentateuch : die Peshitta : Interlinearausgabe Syrisch - Arabisch (Sources Syriaques 7; Antélias: Centre d'Études et de Recherches Orientales; Université des Pères Antonins).

M.N. Gemayel, Tärìkh al-turäth al-'arabi al-mārūnì. 2, al-mu'allifün almawärinah fì al-'ass al-'uthmāni, al-juz' al-awwal (1516-1760 M) / Histoire du Patrimoine Arabe des Maronites. 2.1, Les Auteurs Maronites sous les Ottomans (1516-1760) (Beirut: Éditions du CEDRAC).

St. Griffith, Nightingales in the Mountain of Slaves (Leicester: Christians Aware).

F. Guigain, La récitation orale de la Nowvelle Alliance, selon saint Jean (Paris: Cariscript).

J.-C. Haelewyck \& M. Geerard, Claves apocryphorum Veteris et Novi Testamenti (Turnhout: Brepols).

D. King \& G.A. Kiraz, The Syriac Bible with English Translation: Romans - Corinthians (Surath Kthob; Piscataway, NJ: Gorgias Press).

S. al-Malih, Books and Documents Heritage of Iraqi Minorities (Roma: Un ponte per...). 
F. Millar, Religion and Community in the Roman Near East. Constantine to Mubammad (The Schweich Lectures of the British Academy 2010; Oxford: Oxford University Press).

J. Moolan, Liturgial year: Syro-Malabar Church (Oriental Institute of Religious Studies 380; Kottayam: Oriental Institute of Religious Studies).

J. Moolan, Sacraments of initiation: Syro-Malabar Church (Oriental Institute of Religious Studies 376; Kottayam: Oriental Institute of Religious Studies).

U.R. Nieten, Struktur und Metrum in den syrisch-aramäischen Psalmen und Hymnen (Semitica et Semitohamitica Berolinensia 12; Aachen: Shaker Verlag).

Th. Prieto Peral \& H. Oberkampf, Heimat oder Exil? Zur Lage der Christen im Irak (Neuendettelsau: Erlanger Verlag für Mission und Ökumene).

J.A. Puliurumpil, History of the Syro-Malabar Church (Oriental Institute of Religious Studies 382; Kottayam: Oriental Institute of Religious Studies).

K.M. Rajan, Martyrs, Saints and Prelates of the Syriac Orthodox Church, vol. III (Kottayam: Travancore Syriac Orthodox Publishers).

Ch. Verdeil (ed.), Missions chrétiennes en terre d'Islam (XVIIe-XIXe siècles) (Anthologies de textes et documents missionnaires 5; Turnhout: Brepols).

V. Vesa, Cunoaşterea lui Dumnezen la Sfântul Isaac Sirul (Cluj-Napoca: Editura Renasterea).

D. Winkler (ed.), Syriac Christianity in the Middle East and India (Pro Oriente Studies in the Syriac Tradition 2; Piscataway, NJ: Gorgias Press).

J. Zeki, Das Buch der ergötzlichen Erzäblungen des Bar Hebräus (Studien zur Orientalischen Kirchengeschichte 47; Münster-BerlinVienna-Zurich-London: LIT Verlag) 
P. Zgheib, La représentation picturale syriaque des astres à la limite $d u$ syncrétisme et de l'éclectisme anciens (Kaslik: Presses de l'Université Saint-Esprit de Kaslik).

\section{4}

- : Takesō d-qurrōbō (Awsār slawōto 2; Kottayam: SEERI). [Bilingual, Syriac and English; with Anaphoras of Xystus, Dionysius bar Salibi, and the Fathers]

E.B. Aitken \& J.M. Fossey (eds), The Levant: Crossroads of Late Antiquity. History, Religion and Archaeology / Le Levant: Carrefour de l'Antiquité Tardive. Histoire, religion et archéologie (McGill University Monographs in Classical Archaeology and History 22; Leiden: Brill).

I. Apostolache, Hristologie și mistică în teologia siriană (Craiova: Editura Mitropolia Olteniei).

D. Atanassova \& T. Chronz (eds), $\Sigma \Upsilon N A \Xi I \Sigma K A \Theta O A I K H$. Beiträge zu Gottesdienst und Geschichte der fünf altkirchlichen Patriarchate für Heinzgerd Brakmann zum 70. Geburtstag (Orientalia - Patristica Oecumenica 6/1-2; Münster-Berlin-Vienna-Zurich-London: LIT Verlag).

O. Ayağ, Süryaniler ve Din (Istanbul: Karma Kitaplar).

C. Baffioni, R.B. Finazzi, A.Passoni Dell'Acqua \& E. Vergani (eds), Storia del pensiero religioso nel Vicino Oriente. L'età Bagratide Maimonide - Afraate (Orientalia Ambrosiana 3; Milano: Biblioteca ambrosiana; Roma: Bulzoni) [four articles on Aphrahat].

J. Balty, Les mosä̈ques des maisons de Palmyre (Inventaire des mosaïques antiques de Syrie 2; Bibliothèque archéologique et historique BAH 206; Beyrouth: Presses de l'IFPO)

S.J. Beggiani, Early Syriac Theology: With Special Reference to the Maronite Tradition, 2nd ed. (Washington, DC: Catholic University of America Press). 
V. Berti, L'au-delà de l'âme et l'en-deçà du corps. Morceaux d'anthropologie chrétienne de la mort dans l'église syro-orientale (Paradosis 57; Fribourg).

G. Boccaccini \& J.M. Zurawski (eds), Interpreting 4 Exra and 2 Baruch: international studies (Library of Second Temple studies 87; New York, NY: Bloomsbury Publishing Plc).

S.P. Brock \& L. van Rompay, Catalogue of the Syriac Manuscripts and Fragments in the Library of Deir al-Surian, Wadi al-Natrun (Egypt) (Orientalia Lovanensia Analecta 227; Leuven: Peeters).

S.P. Brock, Syriac Studies. A Classified Bibliography, vol. 2 (1991-2010) (Patrimoine Syriaque 7; Kaslik).

P. Bukovec (ed.), Christlicher Orient im Porträtwissenschaftsgeschichte des Christlichen Orients, Band 1 (Hamburg: Verlag Dr Kovac).

M.S. Cheriyathottam, The Book of Syriac in Malankara / Ktōbō dsuryōyō b-malankara (Kalpetta, Wayanad: C.O. Mathew Foundation).[rohan.mathew7@gmail.com].

S. Chialà, La perla dai molti riflessi. La lettura della Scrittura nei padri siriaci (Magnano: Monastero di Bose).

E. Coda \& C. Martini Bonadeo (eds), De l'Antiquité Tardive au Moyen Agge. Études de logique aristotélicienne et de philosophie grecque, syriaque, arabe et latine offertes à Henri Hugonnard-Roche (Études musulmanes xliv; Paris: Vrin).

M. Conterno, La "descrizione dei tempi" all'alba dell'espansione islamica. Un'indagine sulla storiografia greca, siriaca e araba fra VII e VIII secolo (Millennium Studies 47; Berlin: De Gruyter).

M. Conterno, Temistio orientale. Orazioni temistiane nella tradizione siriaca e araba (Testi del Vicino Oriente antico; Brescia: Paideia).

J. Ferreira, Early Chinese Christianity: the Tang Christian monument and other documents (Strathfield, NSW, Australia: St Pauls). 
E. Fiori, Dionigi Areopagita. Nomi Divini, Teologia Mistica, Epistole: La versione siriaca di Sergio di Réšaynà (VI secolo) (CSCO 656-7; Scr. Syri 252-3; Leuven: Peeters).

J.G. Gebhardt, The Syriac Clementine Recognitions and Homilies: The First Complete Translation of the Text (Nashville, TN: Grave Distractions Publications).

L. Greisiger, Messias - Endkaiser - Antichrist. Politische Apokalyptik unter Juden und Christen des Naben Ostens am Vorabend der arabischen Eroberung (Orientalia Biblica et Christiana 21; Wiesbaden: Harrassowitz).

S. Hayati \& P.S. Stevenson, 'Peri Hermeneias' by Paul the Persian (Duhok: Nawroz University) [Syr. text and English translation].

K.S. Heal \& R.A. Kitchen (eds), Breaking the Mind. New Studies in the Syriac "Book of Steps" (Washington DC: Catholic University of America Press).

M. Heide, Secundus Taciturnus. Die arabischen, äthiopischen und syrischen Textzengen einer didaktischen Novelle aus der römischen Kaiserzeit (Aethiopistische Forschungen 81; Wiesbaden: Harrassowitz).

J. den Heijer, A. B. Schmidt, T. Pataridze (eds), Scripts Beyond Borders. A Survey of Allographic Traditions in the Euro-Mediterranean World (Publications de l'Institut Orientaliste de Louvain 2; Leuven: Peeters).

F. Hellot-Bellier, Chronique de massacres annoncés. Les Assyro-Chaldéens d'Iran et du Hakekari face aux ambitions des empires (1896-1920) (Cahiers d'études syriaques 2; Paris: Geuthner).

G. Herman (ed.), Jews, Christians and Zoroastrians. Religious Dynamics in a Sasanian Context (Judaism in Context 17; Piscataway, NJ: Gorgias Press).

E.D. Hunter \& M. Dickens, Syrische Handschriften. Teil 2: Texte der Berliner Turfansammlung / Syriac Texts from the Berlin Turfan Collection (Verzeichnis der Orientalischen Handschriften in Deutschland 5.2; Berlin: Franz Steiner Verlag). 
Ibn Warraq (ed.), Christmas in the Koran: Luxenberg, Syriac, and the Near Eastern and Judeo-Christian background of Islam (Amherst, New York: Prometheus Books).

A.J. Iskandar, Épigraphie syriaque au Liban. Vol. II. Les épigraphes syriaques dans l'architecture libanaise (Zouk Mekayel: Notre Dame University - Louaizé). [vol. I (Catalogue des épigraphes syriaques au Liban du haut Moyen Áge à 1925) appeared in 2008].

J. Jacob, Ostsyrische Christen und Kurden im Osmanischen Reich des 19. und frühen 20. Jabrhunderts (Orientalia - Patristica - Oecumenica 7; Münster-Berlin-Vienna-Zurich-London: LIT Verlag).

F.S. Jones, The Syriac Pseudo-Clementines. An Early Version of the First Christian Novel (Apocryphes 14; Turnhout: Brepols)

P.B. Kadicheeni, The Mystery of Baptism in the Book 'The Seven Mysteries of the: Church' by Timothy II, Nestorian Patriarch 1318-1332 (Moran Etho 33; Kottayam: SEERI).

R.A. Kitchen, G.A. Kiraz, The Acts of the Apostles according to the Peshitta Bible (Surath Kthob; Piscataway, NJ: Gorgias Press).

M. Kozah, A. Abu-Husayn, S. Shaheen Al-Murikhi \& H. Al Thani (eds), The Syriac Writers of Qatar in the Seventh Century (Gorgias Eastern Christian Studies 38; Piscataway, NJ: Gorgias Press).

J. Loopstra, An East Syrian Manuscript of the Syriac 'Masora' Dated to 899 CE. A Facsimile Reproduction of British Library, Add. MS 12138, vol. 1 (Piscataway, NJ: Gorgias Press).

B. Lourie, N.N. Seleznyov (eds), Syrians and Others: Cultures of the Christian Orient in the Middle Ages (= Scrinium: Revue de patrologie, d'hagiographie critique et d'histoire ecclésiastique 10; Piscataway, NJ: Gorgias Press).

S. Maroki, Les trois étapes de la vie spirituelle chez les Pères syriaques: Jean le solitaire, Isaac de Ninive et Joseph Hazzaya. Source, doctrine et influence (Paris: Éditions l'Harmattan). 
E.G. Mathews, Jacob of Sarug, Homily on the Creation of Adam and the Resurrection of the Dead (Texts from Christian Late Antiquity 37; Piscataway, NJ: Gorgias Press).

E.G. Mathews, The Armenian Prayers attributed to Ephrem the Syrian (Texts from Christian Late Antiquity 36; Piscataway, NJ: Gorgias Press).

A.C. McCollum, Jacob of Sarug's Homilies on Jesus' Temptation (Texts from Christian Late Antiquity 38; Piscataway, NJ: Gorgias Press). [Bedjan, Homs. 82, 126].

D. Michelson, The Practical Christology of Philoxenos of Mabbug (Oxford Early Christian Studies; Oxford: Oxford University Press).

M. Moosa, The Syriac Chronicle of Michael Rabo (the Great). A Universal History from the Creation (Teaneck, NJ: Beth Antioch Press; ISBN 978-1-939682-09-3).

M. Morrigi, A Corpus of Syriac Incantation Bowls. Syriac Magical Texts from Late Antique Mesopotamia (Magical and Religious Literature of Late Antiquity 3; Leiden: Brill).

T. Muraoka, Classical Syriac for Hebraists, 2nd, revised edition (Subsidia et Instrumenta Linguarum Orientis 6; Wiesbaden: Harrassowitz).

A. Müller (ed.), Das Kreuz unter dem Halbmond. Orientalische Christen im Angesicht des 'Arabischen Früblings' (Studien zur Orientalischen Kirchengeschichte 50; Münster-Berlin-Vienna-Zurich-London: LIT Verlag).

G.M. Mushayabasa, Translation Technique in the Peshitta to Ezekiel 1 24. A Frame Semantics Approach (Studia Semitica Neerlandica 63; Leiden: Brill).

A. Nicoletti, From the Mandylion of Edessa to the Shroud (Art and Material Culture in Medieval and Renaissance Europe 1; Leiden: Brill). 
N. Nin, E. Vergani, "In modo bello e ammirabile". Testi su Maria di Efrem il Siro e Severo di Antiochia (Milano: Centro Ambrosiano).

J. Nīsān al-Sanāțī, Mafhūm al-mar'ah inda mār Narsaī [The concept of woman in Mar Narsai] (Dohūk: Dār al-mashriq al-thaqāfiyyah).

M. Oez, Turoyo: the Language of Tur 'Abdin. Modern Aramaic in Practice (Place not stated; Modern Aramaic Press).

B. Özdemir, Süryanilerin Dünü Bugünü I. Dünya Savaşı'nda Süryaniler (Ankara: Türk Tarih Kurumu).

P. Pallath, Constitution of Syro-Malabar hierarchy: a documental study (HIRS publications 82; Changanacherry: HIRS Publications).

M. Pazzini, Lessico concordanziale del Nuovo Testamento siriaco, 2nd ed. (Analecta 64; Milano: Edizioni Terra Santa).

A. Poujeau, Des monastères en partage. Sainteté et pouvoir chez. les chrétiens de Syrie (Nanterre: Publications de la Société d'ethnologie).

M.C. Rouhana, La Création de l'ère patristique à l'ère quantique: un pont entre la science et la religion. Essai en théologie razatique (Dékouaneh, Beyrouth: Monastère Saint Roche; ISBN 978-9953-0-2897-2).

Y. Șādir, Hayāh wa-a'māl al-qiddìs Sim'àn al-'amūdì fì makbtūtah alfätìkean al-suryāni 160 / La vie et les actes de Saint Siméon Stylite (Bayrūt: Dār Șādir). [Includes Vat. Syr. 160 with English and French translations].

Chr.C. Sahner, Among the ruins: Syria past and present (London: Hurst).

Ṣ. Shem'ūn [tr.], Fann al-fașāhah (Dohūk: Dār al-mashriq althaqāfiyyah) [Arabic translation of Antūn of Tagrit's treatise on rhetoric].

A.M. Silvas, Basil of Caesarea, Questions of the Brothers. Syriac Text and English Translation (Texts and Studies in Eastern Christianity 3; Leiden: Brill). 
N. Sims-Williams, Biblical and other Christian Sogdian Texts from the Turfan Collection (Berliner Turfantexte XXXII; Turnhout: Brepols). [Translations from Syriac].

K. Smith, The Martydom and History of Blessed Simeon bar Sabba'e (Persian Martyr Acts in Syriac 3; Piscataway, NJ: Gorgias Press).

M. Sokoloff, A Dictionary of Christian Palestinian Aramaic (Orientalia Lovaniensia Analecta 234; Leuven: Peeters).

M. Sokoloff, Texts of V arious Contents in Christian Palestinian Aramaic (Orientalia Lovaniensia Analecta 235; Leuven: Peeters).

M. Tamcke \& S. Grebenstein (eds), Geschichte, Theologie und Kultur des syrischen Cbristentums. Beiträge zum 7. Deutschen Syrologie-Symposium in Göttingen, Dezember 2011 (Göttinger Orientforschungen, Reihe 1.: Syriaca, Bd. 46; Wiesbaden: Harrassowitz).

S. \& I. Tanoglu, Ortodoks Kilisesi'nin Sütunu Suruclu Süryani Mor Yakup (Istanbul; ISBN 978-9944-5201-2-6).

R.A. Taylor \& C.E. Morrison (eds), Reflections on Lexicography (Perspectives on Linguistics and Ancient Languages 4; Piscataway, NJ: Gorgias Press).

R.W. Thomson, Nonnus of Nisibis, Commentary on the Gospel of Saint John. Translation of the Armenian Text with Introduction and Commentary (Writings from the Islamic World 1; Atlanta: SBL Press).

B. Varghese, Moses bar Kepha: Commentary on Myron (Texts from Christian Late Antiquity 34; Piscataway, NJ: Gorgias Press).

B. Varghese, Moses bar Kepha: Commentary on the Eucharist (Kottayam: Malankara Orthodox Church Publications).

B. Varghese, Book of Guides (Hudaya) or Nomocanon by Gregorios bar Hebraeus. Commentary on the Eucharist (Kottayam: Malankara Orthodox Church Publications). 
B. Varghese, Order of the Anointing of the Sick known as The Service of Qandilo (Kottayam: Malankara Orthodox Church Publications).

P.K. Varghese, Introducing the Worship in Assyrian Church of the East. The Divine Offices, Twelve Seasons, the Holy Qurbana (Thrissur: Mar Augin Church).

P.K. Varghese, Gpìtā da-shrärā. The True Vine (Thrissur; ISBN 97893-81117-13-2). [Poems, Syriac and Malayalam].

D. Vechoor, The Sacrament of Reconciliation. Learning from the East and the West (OIRSI 394; Kottayam: Oriental Institute of Oriental Studies).

É. Villey (ed.), Les sciences en syriaque (Études syriaques 11; Paris, Geuthner).

É. Villey \& H. Hugonnard-Roche (eds), Astronomie et cosmographie syriaques. Recueil d'articles de François Nau (Scholars of Syriac: Collected Works 1; Piscataway, NJ: Gorgias Press). 
Bibliography of Syriac and Christian Arabic Studies in
Russian, 20141

\section{Grigory M. Kessel, PhilipPS UniVERSität - MARbURG}

NiKOLAI N. SELEZNYOV, INSTITUTE FOR ORIENTAL AND CLASSICAL STUDIES, RUSSIAN STATE UNIVERSITY FOR THE HUMANITIES

\section{Addenda}

Бураев, А.И. [Alexey I. Buraev], “Несторианство в степях Центральной Азии" ["Nestorians in the steppes of the Central Asia"], В мире научных открылтий 11:3/47 (2013): 5160.

Гусев, А.B. [Andrey V. Gusev], "Проповедь «греческого Ефрема» на праздник Обновления. Перевод и предварительный комментарий” [“The Sermon of the 'Greek Ephrem' on the feast of Encaenia (Oratio de sancto sepulcro habita Hierosolymis): Translation and preliminary observations"], Вестник Екатеринбургской духовной семинарии 2/ 6 (2013): 179-209.

Аавыденков, ОАег, прот. [archpr. Oleg Davydenkov], “Булус арРахиб и его творения. (Приложение: Булус ар-Рахиб. Богословские и философские трактаты; пер. с араб.)" ["Būlus ar-Rāhib and his works. (Appendix: Būlus ar-Rāhib. Theological and philosophical treatises; tr. from Arabic by archpr. Oleg Davydenkov)"], Арабъ--христиане в истории и suтературе Ближнего Востока [Arab Christians in the history and literature of the Near East / ed. Natalya G. Golovnina. Москва: Православный Свято-Тихоновский гуманитарный

${ }^{1}$ See also: Kessel, G.M., Seleznyov, N.N., "Syrian Christianity: Recent Bibliography in Russian, [2000-2008]", Scrinium 2 (2009): 481-487; Scrinium 4 (2009): 394-402; Seleznyov, N.N., "Annotated Bibliography of Syriac Studies in Russian, 2009”, Hugoye 13:1 (2010): 108-117; Kessel, G.M., Seleznyov, N.N., Bibliography of Syriac and Christian Arabic Studies in Russian, 2010-2012, Hugoye 16:1 (2013): 134-155; Kessel, G.M., Seleznyov, N.N., Bibliography of Syriac and Christian Arabic Studies in Russian, 2013, Hugoye 17:1 (2014): 132-140. 
университет, 2013. (Серия «Аитературное наследие и история Христианского Востока»), pp. 62-149. - ISBN 9785-7429-0816-6.

Заболотный, Е.A. [Evgeny A. Zabolotnyi], "Был ми Несторий православным? (По поводу статей М. Анастоса и А. Ае A^^ё)" ["Was Nestorius Orthodox? (On the articles by M. Anastos and A. de Halleux"] Вестник Православного СвятоТихоновского гуманитарного университета 35:5 (2013): 30-40.

Keсce $\lrcorner$, Г.M. [Grigory M. Kessel], Review of Mémorial Monseigneur Joseph Nasrallah / éd. par P. Canivet (†), J.-P. Rey-Coquais. Damas: Institut Français du Proche Orient, 2006. (Publications de l'Institut Français de Damas; 221). XVIII, 371 pp., Богословские трудъ 45 (2013): 482-487.

Кессель, Г.M. [Grigory M. Kessel], Review of Christian-Muslim Relations. A Bibliographical History. Vol. 1 (600-900) / Ed. D. Thomas, B. Roggema. Leiden: Brill, 2009. (The History of Christian-Muslim Relations, 11). 957 pр., Богословские труды 45 (2013): 477-481.

Константинопольский, И. Г. [Ivan G. Konstantinopol'skii], "Бейрутская метопись АбАалмаха ибн Михаила Трада. (Приложение: Краткая история епископов, восходивших на высокую архиерейскую кафеАру города Бейрута; пер. с apaб.)" ["The Chronicle of 'Abdallāh ibn Mīha'îl TTrād. (Appendix: Short history of the bishops who were elevated to the high hierarchal see of the city of Beirut; tr. from Arabic by Ivan G. Konstantinopol'skij)"'], Арабъ-христиане в истории и suтературе Ближнего Востока [Arab Christians in the bistory and literature of the Near East] / ed. Natalya G. Golovnina. Москва: Православный Свято-Тихоновский гуманитарный университет, 2013. (Серия «Аитературное наследие и история Христианского Востока»), pp. 150-201. - ISBN 978-5-7429-0816-6.

Кузенков, П.В. [Pavel V. Kuzenkov], “Описание затмения 7 августа 1366 г. в русской метописи" ["Description of the eclipse of September the $7^{\text {th }}$ AD 1366 in a Russian 
manuscript"], Арабъ-христиане в истории и sитературе Ближнего Востока [Arab Christians in the history and literature of the Near East] / ed. Natalya G. Golovnina. Москва: Православный Свято-Тихоновский гуманитарный университет, 2013. (Серия «Аитературное наследие и история Христианского Востока»), pp. 220-226. - ISBN 978-5-7429-0816-6.

Кункова, В.И. [Veronika I. Kunkova], “Сведения о халифе А^Мансуре в рукописи сочинения Мухтасар ад-дувал Бар Гебрея" ["An account on Caliph al-Manșūr in the manuscript of the Mubtassar ad-dwwal of Bar Hebraeus"], Восточный архив 1/27 (2013): 4-8.

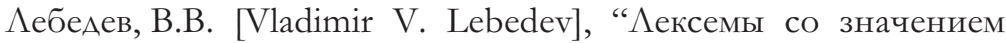
«Бог» в богослужебных книгах арабов-христиан” [“Lexemes with a meaning of 'God' in prayer books of the Christian Arabs"], Вестник Православного Свято-Тихоновского гуманитарного университета 35:5 (2013): 46-58.

Майоров, A.B. [Alexander V. Mayorov], “Письмо римского папы Иннокентия IV золотоордынскому хану Сартаку (текст, перевод, комментарий)" ["Pope Innocent IV's letter to Sartaq Khan of the Golden Horde (text, translation, notes)"], Mongolica 10 (2013): 74-81.

See also: Idem, "Письмо римского папы Иннокентия IV золотоордынскому удельному правителю Сартаку" ["Роре Innocent IV's letter to Sartaq the governor of the Golden Horde"], Гасьрлар авазы (Эхо веков) 1-2 (2012): 13-22; Idem., "Монгольская угроза и экуменические процессы середины XIII в.” [“The Mongol menace and the ecumenical processes in the $13^{\text {th }}$ c."'], Евразия: духовные традичии народов 3 (2012): 80-94; Idem., “Аист римського папи Інокентія IV золотоординському ханові Сартаку" ["Pope Innocent IV's letter to Sartaq the governor of the Golden Horde", in Ukrainian], Княжа доба: історія і культура 6 (2012): 173-186.

Моисеева, С.А. [Sofia A. Moiseeva], “Житие Антиохийского патриарха Христофора как памятник арабо-мелькитской агиографии кон. X - нач. XI в. (Приложение: Ибрахим 
ибн Юханна. Житие Антиохийского патриарха Христофора (пер. с араб.))" [“The Life of Christopher, Patriarch of Antioch, as an example of Arab Melkite hagiography of the late $10^{\text {th }}$ and early $11^{\text {th }}$ centuries. (Appendix: Ibrāhīm ibn Yuhannā. The Life of the Patriarch of Antioch (tr. from Arabic by Sofia A. Moiseeva))"], Арабъ-христиане в истории и литературе Ближнего Востока [Arab Christians in the history and literature of the Near East / ed. Natalya G. Golovnina. Москва: Православный Свято-Тихоновский гуманитарный университет, 2013. (Серия «Аитературное наследие и история Христианского Востока»), pp. 6-61. - ISBN 978-57429-0816-6.

Моисеева, C.A. [Sofia A. Moiseeva], Review of Translating the Bible into Arabic: historical, text-critical and literary aspects / ed. by Sara Binay and Stefan Leder. Beirut: Orient-Institut Beirut; Wurzburg: Ergon Verlag Wurzburg in Kommission, 2012. (Beiruter Texte und Studien; 131). 150, 127 рр.: ill., Вестник Православного Свято-Тихоновского гуманитарного университета 35:5 (2013): 163-169.

Морозов, А.А. [Dmitry A. Morozov], “Каршуни” [“Karshūnï”], Православная Энииклопедия, Т. 31 (2013), рр. 463-465.

Панченко, К.A. [Constantin A. Panchenko], “Забытая катастрофа. К реконструкции последствий Александрийского крестового похода 1365 г. на Христианском Востоке" ["The forgotten disaster. On the reconstruction of the sequences of the Alexandrian crusade (1365) in the Christian Orient"], Арабы-христиане в истории и литературе Ближнего Востока [Arab Christians in the history and literature of the Near East] / ed. Natalya G. Golovnina. Москва: Православный Свято-Тихоновский гуманитарный университет, 2013. (Серия «Аитературное наследие и история Христианского Востока»), рр. 202-219. - ISBN 978-5-7429-0816-6.

Панченко, К.А. [Constantin A. Panchenko], "Православные врачи на арабском Востоке" [“The Melkite physicians in the 
Arabic East"], Вестник Православного Свято-Тихоновского гуманитарного университета 35:5 (2013): 59-75.

Панченко, К.А. [Constantin A. Panchenko], “Отношения межАу народами Восточной Европы и арабами-христианами в XVII веке" ["The Relations between East European peoples and the Arab Christians in the $17^{\text {th }}$ c.'], Вестник иерковной истории 1-2/29-30 (2013): 388-396.

Притула, A.А. [Anton D. Pritula], "Бар 'Эбройо (Григорий, сын Аарона) и Хамис бар Кардахе: Из Ниневии в Фарс" [“Bar 'Eḅrōyō (Grigorius, son of Aaron) and Kāmīs bar Qardāḥē: From Nineveh to Fars"], Commentationes Iranicae. Сборник статей к 90-летию ВАадимира Ароновича Аившица / ed. by S.R. Tohtasyev and P.B. Lurje. Санкт-Петербург: НесторИстория, 2013, pp. 508-514. - ISBN 978-5-4469-0127-2.

Таварткиладзе, А.T. [David T. Tavartkiladze], “Грамота Антиохийского патриарха Аорофея II (1512)" [“A letter of Dorotheus II, Patriarch of Antioch (1512)"], Арабы-христиане в истории и литературе Ближнего Востока [Arab Christians in the bistory and literature of the Near East] / ed. Natalya G. Golovnina. Москва: Православный Свято-Тихоновский гуманитарный университет, 2013. (Серия «Аитературное наследие и история Христианского Востока»), рp. 227-270. - ISBN 978-5-7429-0816-6.

Французов, С.А. [Serge A. Frantsouzoff], “Чудо Богородичъг в Аmрибе: Текстологические особенности и специфика содержания" ["The Miracle of St. Mary in Atrib: Textological peculiarities and specific features of its contents"], Вестник Православного Свято-Тихоновского гуманитарного университета 35:5 (2013): 97-108, 133-160.

Якушев, М.И. [Mikhail I. Yakushev]. Антиохийский и Иерусалимский патриархаты в политике Российской империи. 1830-e - начало XX века [Patriarchates of Antioch and Jerusalem in the policy of the Russian Empire. 1830s - early 20th century]. Москва: ИнАрик, 2013. 536 pp. - ISBN: 978-5-91674-272-5. 
Ченцова, В.Г. [Vera G. Tchentsova], "Первое путешествие Антиохийского патриарха Макария III ибн аз-За'има в Москву (1652-1659): контакты и конфликты” [“The first travel of Macarius III ibn al-Zaiim, Patriarch of Antioch, to Moscow (1652-1659): Contacts and conflicts"], Вестник Православного Свято-Тихоновского гуманитарного университета 35:5 (2013): 116-129.

2014

Акики, Ж. [Jean Akiki, Rev.] "Ритуал слез у св. Исаака Ниневийского” [“The Ritual of Tears by Isaac of Niniveh"] Преподобныии Исаак Сирин и его духовное наследие. Proceedings of the First International Patristic Conference "Saint Isaac the Syrian and his Spiritual Legacy" (October 10 10 $-11^{\text {th }}$, 2013, Moscow) / Ss. Cyril and Methodius Theological Institute for Postgraduate Studies; ed. by Alexey R. Fokin, Maksim G. Kalinin, Evgeny A. Pilipenko. Москва: Общецерковная аспирантура и докторантура им. свв. Кирилка и Мефодия, 2014, pp. 225-241. - ISBN 978-5-9065-4307-3.

Аржанов, Ю.Н. [Yury N. Arzhanov], “Физика Аристотеля в сирийской школе" ["Physica of Aristotle in the Syriac school'], Miscellanea Orientalia Christiana / Russian State University for the Humanities, Institute for Oriental and Classical Studies; Ruhr-Universität Bochum, Seminar für Orientalistik und Islamwissenschaft; ed. by Nikolai $\mathrm{N}$. Seleznyov, Yury N. Arzhanov. Москва: Российский государственный гуманитарный университет, Институт восточных культур и античности, 2014, pp. 58-91. - ISBN 978-5-98604-419-4.

Баранов, В.А. [Vladimir Baranov], “Ангель в облике святых: сирийская традиция в Константинополе” [“Angels in the Likeness of Saints: Syriac Tradition in Constantinople in the $8^{\text {th }}$ c."'], Преподобныги Исаак Сирин и его духовное наследие. Proceedings of the First International Patristic Conference "Saint Isaac the Syrian and his Spiritual Legacy" (October 10"th 11 th 2013, Moscow) / Ss. Cyril and Methodius Theological 
Institute for Postgraduate Studies; ed. by Alexey R. Fokin, Maksim G. Kalinin, Evgeny A. Pilipenko. Москва: Общецерковная аспирантура и Аокторантура им. свв. Кирилма и Мефодия, 2014, рр. 315-332. - ISBN 978-59065-4307-3.

Барский, Е.В., Калинин, М.Г. [Evgeny V. Barsky, Maksim G. Kalinin], "Не будьте как дети: ААам в Третьем томе Исаака Сирина" ["Do not be like children: Adam in the Third Part of Isaac the Syrian"], Miscellanea Orientalia Christiana / Russian State University for the Humanities, Institute for Oriental and Classical Studies; Ruhr-Universität Bochum, Seminar für Orientalistik und Islamwissenschaft; ed. by Nikolai N. Seleznyov, Yury N. Arzhanov. Москва: Российский государственный гуманитарный университет, Институт восточных культур и античности, 2014, pp. 26-44. - ISBN 978-5-98604-419-4.

Барский, Е.В., Калинин, М.Г. [Evgeny V. Barsky, Maksim G. Kalinin], “Адам в 3-м томе св. Исаака Сирина” [“Adam in the $3^{\text {rd }}$ Part of Saint Isaac the Syrian"], Преподобныци Исаак Сирин и его духовное наследие. Proceedings of the First International Patristic Conference "Saint Isaac the Syrian and his Spiritual Legacy" (October 10 $10^{\text {th }}-11^{\text {th }}, 2013$, Moscow) / Ss. Cyril and Methodius Theological Institute for Postgraduate Studies; ed. by Alexey R. Fokin, Maksim G. Kalinin, Evgeny A. Pilipenko. Москва: Общецерковная аспирантура и Аокторантура им. свв. Киримла и Мефодия, 2014, рр. 162 172. - ISBN 978-5-9065-4307-3.

Биттон-Ашкелони, Б. [Brouria Bitton-Ashkelony], “Приведенные к тишине: Исаак Сирин и Иоанн Аальятский о самопреображении" ["Reduced to a State of Silence: Isaac of Nineveh and John of Dalyatha on Self-transformation"] Преподобныий Исаак Сирин и его духовное наследие. Proceedings of the First International Patristic Conference "Saint Isaac the Syrian and his Spiritual Legacy" (October 10 10 $-11^{\text {th }}$, 2013, Moscow) / Ss. Cyril and Methodius Theological Institute for Postgraduate Studies; ed. by Alexey R. Fokin, Maksim G. Kalinin, Evgeny A. Pilipenko. Москва: Общецерковная 
аспирантура и докторантура им. свв. Кирилма и Мефодия, 2014, pp. 242-258. - ISBN 978-5-9065-4307-3.

Бэр, Иоанн, прот. [John Behr, Rev.] "Преподобный Исаак Ниневийский о Кресте Христовом" ["St Isaac the Syrian on the Cross"], Преподобный Исаак Сирин и его духовное наследие. Proceedings of the First International Patristic Conference "Saint Isaac the Syrian and his Spiritual Legacy" (October 10 $0^{\text {th }}$ 11th, 2013, Moscow) / Ss. Cyril and Methodius Theological Institute for Postgraduate Studies; ed. by Alexey R. Fokin, Maksim G. Kalinin, Evgeny A. Pilipenko. Москва: Общецерковная аспирантура и Аокторантура им. свв. Кирилма и Мефодия, 2014, рр. 125-136. - ISBN 978-59065-4307-3.

Брок, С. [Sebastian Brock], "Псалмопение и молитва у Исаака Сирина" ["Prayer and Psalmody in St Isaac"], Преподобныци Исаак Сирин и его духовное наследие. Proceedings of the First International Patristic Conference "Saint Isaac the Syrian and his Spiritual Legacy" (October 10 th $-11^{\text {th }}, 2013$, Moscow) / Ss. Cyril and Methodius Theological Institute for Postgraduate Studies; ed. by Alexey R. Fokin, Maksim G. Kalinin, Evgeny A. Pilipenko. Москва: Общецерковная аспирантура и Аокторантура им. свв. Кирилла и Мефодия, 2014, рр. 188 198. - ISBN 978-5-9065-4307-3.

Бумажнов, А.Ф. [Dmitrij F. Bumazhnov], “Неизвестные христианские паралмели мусульманской мегенды о разговоре Иисуса с черепом" [“Unknown Christian parallels to the Muslim legend on the dialogue between Jesus and the skull'], Miscellanea Orientalia Christiana / Russian State University for the Humanities, Institute for Oriental and Classical Studies; Ruhr-Universität Bochum, Seminar für Orientalistik und Islamwissenschaft; ed. by Nikolai N. Seleznyov, Yury N. Arzhanov. Москва: Российский государственный гуманитарный университет, Институт восточных культур и античности, 2014, рр. 248-257. ISBN 978-5-98604-419-4. 
Василий (Иверский), архим. [Vasileios Iviritis, Archim.], “Ауховная связь аввы Исаака Сирина и Ф.M. Аостоевского" [“The Spiritual Relation of Abba Isaac and Dostoyevsky"], Преподобный Исаак Сирин и его духовное Hacredue. Proceedings of the First International Patristic Conference "Saint Isaac the Syrian and his Spiritual Legacy" (October 10 $0^{\text {th }}-11^{\text {th }}, 2013$, Moscow) / Ss. Cyril and Methodius Theological Institute for Postgraduate Studies; ed. by Alexey R. Fokin, Maksim G. Kalinin, Evgeny A. Pilipenko. Москва: Общецерковная аспирантура и Аокторантура им. свв. Кирилма и Мефодия, 2014, рр. 378-385. - ISBN 978-59065-4307-3.

Габриэль (Бунге), схиархим. [Gabriel Bunge, Archim.] "С греческого на сирийский и обратно: об одной цитате из Евагрия Понтийского" [“From Greek Evagrius to Syriac Evagrius, and Backward"], Преподобныгй Исаак Сирин и его духовное наследие. Proceedings of the First International Patristic Conference "Saint Isaac the Syrian and his Spiritual Legacy" (October 10 $10^{\text {th }}-11^{\text {th }}, 2013$, Moscow) / Ss. Cyril and Methodius Theological Institute for Postgraduate Studies; ed. by Alexey R. Fokin, Maksim G. Kalinin, Evgeny A. Pilipenko. Москва: Общецерковная аспирантура и Аокторантура им. свв. Кирилма и Мефодия, 2014, рр. 199-212. - ISBN 978-59065-4307-3.

Головнина, Н.Г. [Natalia G. Golovnina], “Жанровая система аскетической письменности и ее особенности в сирийской митературе" ["The Genre System of Ascetic Writings and Its Specifics in the Syriac Literature"], Преподобныгй Исаак Сирин и его духовное наследие. Proceedings of the First International Patristic Conference "Saint Isaac the Syrian and his Spiritual Legacy" (October 10 10 $-11^{\text {th }}, 2013$, Moscow) / Ss. Cyril and Methodius Theological Institute for Postgraduate Studies; ed. by Alexey R. Fokin, Maksim G. Kalinin, Evgeny A. Pilipenko. Москва: Общецерковная аспирантура и докторантура им. свв. Кирилма и Мефодия, 2014, pp. 274-287. - ISBN 978-59065-4307-3.

Аавыденков, Олег, прот. [archpr. Oleg Davydenkov], 
"Интел^ектуальная аналогия в тринитарном богословии арабо-христианских писателей IX-XIII вв." [“Intellectual analogy in the Trinitarian theology of Arab Christian authors of the IX-XIII c."], Вестник Московского университета (Серия 7: Философия) 5 (2014): 81-91. Four appendices: Russian translations of the works by Yahyā b. 'Adī, Ibn Zur'a, and Muhyī l-Dīn al-Iṣfahānī (pp. 92-102).

Аионисий (ШАёнов), игум. [Dionisiy Schlenov, Hegum.], "Исаак Сирин и Симеон Новый Богослов как учители безмолвия" ["Isaac the Syrian and Symeon the New Theologian as Teachers of Silence"], Преподобньгй Исаак Сирин и его духовное Hacredue. Proceedings of the First International Patristic Conference "Saint Isaac the Syrian and his Spiritual Legacy" (October 10 $0^{\text {th }}-11^{\text {th }}, 2013$, Moscow) / Ss. Cyril and Methodius Theological Institute for Postgraduate Studies; ed. by Alexey R. Fokin, Maksim G. Kalinin, Evgeny A. Pilipenko. Москва: Общецерковная аспирантура и Аокторантура им. свв. Кирилма и Мефодия, 2014, рр. 333-348. - ISBN 978-59065-4307-3.

Егорова, M.C. [Marina S. Egorova], “Аскетический текст в Аревнерусской традиции: поучения преподобного Исаака Сирина и автокоммуникация" [“Ascetic Text in the Old Russian Tradition: Writings of Saint Isaac the Syrian and Autocommunication"], Преподобный Исаак Сирин и его духовное нacsedue. Proceedings of the First International Patristic Conference "Saint Isaac the Syrian and his Spiritual Legacy" (October 10 $0^{\text {th }}-11^{\text {th }}, 2013$, Moscow) / Ss. Cyril and Methodius Theological Institute for Postgraduate Studies; ed. by Alexey R. Fokin, Maksim G. Kalinin, Evgeny A. Pilipenko. Москва: Общецерковная аспирантура и Аокторантура им. свв. Кирилма и Мефодия, 2014, рр. 363-377. - ISBN 978-59065-4307-3.

Заболотный, Е.A. [Evgeny A. Zabolotnyi], “Христология Церкви Востока: основные направления развития в Vнач. VII в." [“The Christology of the Church of the East: the main trends of development from the fifth to early seventh centuries"] Вестник Православного Свято-Тихоновского 
гуманитарного университета, Серия III: Фимология, 40:5 (2014): 33-44.

"Издания оригинального текста и переводы творений Исаака Сирина. Таблицы соответствий (Приложения I-II)" ["Editions of texts attributed to St. Isaac the Syrian and their translations. Tables of correspondence (Appendices I-II)"], Преподобный Исаак Сирин и его духовное наследие. Proceedings of the First International Patristic Conference "Saint Isaac the Syrian and his Spiritual Legacy" (October 10 10 $-11^{\text {th }}, 2013$, Moscow) / Ss. Cyril and Methodius Theological Institute for Postgraduate Studies; ed. by Alexey R. Fokin, Maksim G. Kalinin, Evgeny A. Pilipenko. Москва: Общецерковная аспирантура и докторантура им. свв. Кирилма и Мефодия, 2014, pp. 409-420. - ISBN 978-5-9065-4307-3.

И^арион (А^феев), митр. [Hilarion Alfeyev, Metr.], “В поисках Ауховного жемчуга. Преподобный Исаак Сирин и его творения" ["In Search of a Spiritual Pearl: St. Isaac the Syrian and his Works"], Преподобный Исаак Сирин и его духовное Hacsedue. Proceedings of the First International Patristic Conference "Saint Isaac the Syrian and his Spiritual Legacy" (October 10 $0^{\text {th }}-11^{\text {th }}, 2013$, Moscow) / Ss. Cyril and Methodius Theological Institute for Postgraduate Studies; ed. by Alexey R. Fokin, Maksim G. Kalinin, Evgeny A. Pilipenko. Москва: Общецерковная аспирантура и Аокторантура им. свв. Кирилма и Мефодия, 2014, рр. 16-43. - ISBN 978-5-90654307-3.

Калинин, М.Г. [Maksim G. Kalinin] see Барский, Е.В., Калинин, М.Г.

Калинина, T.M. [Tatyana M. Kalinina], “А^-Мас'уди о первых шести Вселенских Соборах и разногласиях на них" [“AlMas' ùdī on the first six Ecumenical Councils and their controversies"], Великая схизма. Религии мира до и после разделения черквей. Тезисы докладов и сообщений XVI МежАународной конференции по истории религии и религиоведению (Севастополь 26-31 мая 2014). Севастополь, 2014, р. 20. 
Кессель, Г.M. [Grigory M. Kessel], "Исаак Ниневийский. Ава трактата из новонайденного собрания" [“Two treatises from the newly discovered collection of Isaac of Nineveh"], Miscellanea Orientalia Christiana / Russian State University for the Humanities, Institute for Oriental and Classical Studies; Ruhr-Universität Bochum, Seminar für Orientalistik und Islamwissenschaft; ed. by Nikolai N. Seleznyov, Yury N. Arzhanov. Москва: Российский государственный гуманитарный университет, Институт восточных культур и античности, 2014, pp. 45-57. - ISBN 978-5-98604-419-4.

Kессель, Г.M. [Grigory M. Kessel], Рукописное наследие прп. Исаака Сирина: обзор сирийских рукописей” [“Manuscript Heritage of Saint Isaac the Syrian: a Survey of the Extant Syriac Manuscripts"], Преподобный Исаак Сирин и его духовное наследие. Proceedings of the First International Patristic Conference "Saint Isaac the Syrian and his Spiritual Legacy" (October 10 $10^{\text {th }}$ 11 th, 2013 , Moscow) / Ss. Cyril and Methodius Theological Institute for Postgraduate Studies; ed. by Alexey R. Fokin, Maksim G. Kalinin, Evgeny A. Pilipenko. Москва: Общецерковная аспирантура и Аокторантура им. свв. Кирилма и Мефодия, 2014, рр. 44-65. - ISBN 978-5-90654307-3.

Кьяма, C. [Sabino Chialà, Br.], “Арабский перевод творений св. Исаака Сирина: канал трансляции сирийской христианской митературы” [“The Arabic Version of Saint Isaac the Syrian: A Channel of Transmission of Syriac Literature"], Преподобныгй Исаак Сирин и его духовное наследие. Proceedings of the First International Patristic Conference "Saint Isaac the Syrian and his Spiritual Legacy" (October 10th 11 th 2013, Moscow) / Ss. Cyril and Methodius Theological Institute for Postgraduate Studies; ed. by Alexey R. Fokin, Maksim G. Kalinin, Evgeny A. Pilipenko. Москва: Общецерковная аспирантура и Аокторантура им. свв. Кирилла и Мефодия, 2014, рр. 89-99. - ISBN 978-5-90654307-3. 
Аявданский, А.К. [Alexey K. Lyavdansky], “Заметки о мексических новоарамеизмах в классическом сирийском" ["Notes on lexical Neo-Aramaisms in Classical Syriac"], Вестник Российского государственного гуманитарного университета (Series “Востоковедение. Африканистика”) 6/128 (2014), pp. 51-65.

Михайлов, С.C. [Sergey S. Mikhailov], "Городская диаспора, созданная Первой мировой войной. Ассирийские беженцы в Москве в 1920-х гг." [“An urban diaspora created by the World War I. Assyrian refugees in Moscow in 1920s"] in: Война. Общество. Человек. Материалы международной научно-практической конференции. Университет Российской Академии Образования, Нижегородский филиал. 21 февраля 2014 года. Нижний Новгород, 2014, pp. 64-75.

Морозов, А.A. [Dmitry A. Morozov], "Новая работа по ранней истории текстов Библии на араббском языке” [“A new book on the early history of the text of the Arabic Bible. A review of Sidney H. Griffith, The Bible in Arabic: The Scriptures of the "People of the Book" in the Language of Islam], Miscellanea Orientalia Christiana / Russian State University for the Humanities, Institute for Oriental and Classical Studies; Ruhr-Universität Bochum, Seminar für Orientalistik und Islamwissenschaft; ed. by Nikolai N. Seleznyov, Yury N. Arzhanov. Москва: Российский государственный гуманитарный университет, Институт восточных культур и античности, 2014, pp. 385401. - ISBN 978-5-98604-419-4.

Морозов, A.A. [Dmitry A. Morozov], “Мезгить: отражение каирского Аиалекта в Аревнерусской митературе" ["Мезгить: A Testimony of Cairo Arabic Phonetics in the Old Russian Literature"], Каптеревские чтения 12 (2014), pp. 9-14.

Мусхелишвили, Н. $\Lambda$. [Nikolai L. Muskhelishvili], Review of Селезнев, Н.H. [Nikolai N. Seleznyov], Pax Christiana et Pax Islamica: Из истории менкконфессиональныхх связей на средневековом Ближнем Востоке [Pax Christiana et Pax Islamica: On the History of Interconfessional Relations in the Medieval Near East]. (Orientalia et 
Classica, XLV). Москва: Российский государственный гуманитарный университет, Институт восточных культур и античности, 2014. - 264 pp. - ISBN 978-5-7281-1594-6, Религиоведение 3 (2014): 196-197.

Панченко, К.А. [Constantin A. Panchenko], “Вспомнить прошлое: Антиохийский Патриарх Макарий III аз-За'йм как историк" ["To recall the past: Patriarch Macarius of Antioch as historian"], Miscellanea Orientalia Christiana / Russian State University for the Humanities, Institute for Oriental and Classical Studies; Ruhr-Universität Bochum, Seminar für Orientalistik und Islamwissenschaft; ed. by Nikolai N. Seleznyov, Yury N. Arzhanov. Москва: Российский государственный гуманитарный университет, Институт восточных культур и античности, 2014, pp. 359-384. ISBN 978-5-98604-419-4.

Патаридзе, Т. [Tamara Pataridze], “Существуют ми переводы с сирийского языка на грузинский?” [“Do the translations from Syriac into Georgian exist?"], Miscellanea Orientalia Christiana / Russian State University for the Humanities, Institute for Oriental and Classical Studies; Ruhr-Universität Bochum, Seminar für Orientalistik und Islamwissenschaft; ed. by Nikolai N. Seleznyov, Yury N. Arzhanov. Москва: Российский государственный гуманитарный университет, Институт восточных культур и античности, 2014, pp. 185206. - ISBN 978-5-98604-419-4.

Патаридзе, Т. [Tamara Pataridze], “История зарожАения переводов трудов прп. Исаака Сирина и их распространения в $\Lambda$ авре св. Саввы" ["Isaac from the Monastery of St Sabbas. The History of the Origin of Multiple Translations of Saint Isaac the Syrian Works and Their Distribution in the Holy Lavra"], Преподобный Исаак Сирин и его духовное наследие. Proceedings of the First International Patristic Conference "Saint Isaac the Syrian and his Spiritual Legacy" (October 10 $0^{\text {th }}-11^{\text {th }}, 2013$, Moscow) / Ss. Cyril and Methodius Theological Institute for Postgraduate Studies; ed. by Alexey R. Fokin, Maksim G. Kalinin, Evgeny A. Pilipenko. Москва: Общецерковная аспирантура и докторантура им. 
свв. Кирилма и Мефодия, 2014, рр. 66-79. - ISBN 978-59065-4307-3.

Пирар, М. [Marcel Pirard], "Критическое изАание греческого перевода Подвижнических слов преподобного Исаака Сирина" ["Critical edition of the Greek translation of Saint Isaac the Syrian's ascetical Homilies" (Monastery of Iberon, 2012)], Преподобныгй Исаак Сирин и его духовное наследие. Proceedings of the First International Patristic Conference "Saint Isaac the Syrian and his Spiritual Legacy" (October 10 $10^{\text {th }}$ 11 th, 2013, Moscow) / Ss. Cyril and Methodius Theological Institute for Postgraduate Studies; ed. by Alexey R. Fokin, Maksim G. Kalinin, Evgeny A. Pilipenko. Москва: Общецерковная аспирантура и Аокторантура им. свв. Кирилма и Мефодия, 2014, pp. 80-88. - ISBN 978-5-90654307-3.

Попова, О.C. [Olga S. Popova], “Образ Исаака Сирина в византийском искусстве XIV в." [“The Image of Saint Isaac the Syrian in the Byzantine Art of the 14th c."], Преподобный Исаак Сирин и его духовное наследие. Proceedings of the First International Patristic Conference "Saint Isaac the Syrian and his Spiritual Legacy" (October 10 $0^{\text {th }}-11^{\text {th }}, 2013$, Moscow) / Ss. Cyril and Methodius Theological Institute for Postgraduate Studies; ed. by Alexey R. Fokin, Maksim G. Kalinin, Evgeny A. Pilipenko. Москва: Общецерковная аспирантура и Аокторантура им. свв. Кирилма и Мефодия, 2014, рр. 349362, 421ff. (ills.). - ISBN 978-5-9065-4307-3.

Притула, A.А. [Anton D. Pritula], "Syroturcica: Авуязычное строфическое стихотворение монгольского времени" ["Syroturcica: Bilingual poem from the Mongol time"], Miscellanea Orientalia Christiana / Russian State University for the Humanities, Institute for Oriental and Classical Studies; Ruhr-Universität Bochum, Seminar für Orientalistik und Islamwissenschaft; ed. by Nikolai N. Seleznyov, Yury N. Arzhanov. Москва: Российский государственный гуманитарный университет, Институт восточных культур и античности, 2014, pp. 287-308. - ISBN 978-5-98604-419-4. 
Притула, A.A. [Anton D. Pritula], Восточносирийский гимнографический сборник ВарАа̄ (XIII-XVI вв.): Исследование, публикачия текстов [The East-Syriac collection of hymns Wardā $\left(13^{\text {th }}-16^{\text {th }}\right.$ c.): Monograph and publication of texts]. (Христианский Восток. Серия, посвященная изучению христианской культуры народов Азии и Африки, Т. 7 (XIII), новая серия). Ч. 1: монография / научн. реА. Н.Н. Селезнев; Ч. 2: тексты, перевод / научн. ред. Г.М. Кессель. Санкт-Петербург: ИзАательство Государственного Эрмитажа, 2014. 680 pp. - ISBN 978-5-93572-590-7.

Сальвестрони, С. [Simonetta Salvestroni], “Прп. Исаак Сирин и творчество Ф. М. Аостоевского" ["St Isaac the Syrian and Dostoyevsky"], Преподобныги Исаак Сирин и его духовное Hacnedue. Proceedings of the First International Patristic Conference "Saint Isaac the Syrian and his Spiritual Legacy" (October 10 $10^{\text {th }}-11^{\text {th }}, 2013$, Moscow) / Ss. Cyril and Methodius Theological Institute for Postgraduate Studies; ed. by Alexey R. Fokin, Maksim G. Kalinin, Evgeny A. Pilipenko. Москва: Общецерковная аспирантура и Аокторантура им. свв. Кирилла и Мефодия, 2014, рр. 386-397. - ISBN 978-59065-4307-3.

Селезнев, H.H. [Nikolai N. Seleznyov], Йоханнан Бар 3о би и его «Истолкование таин»: Критический текст, перевод, исследование [John Bar Zöbì and his Explanation of the Mysteries: Critical text, Russian translation from Syriac, and Investigation]. Москва: Российский государственный гуманитарный университет, Институт восточных культур и античности, 2014. - 224 pp. - ISBN 978-5-98604-444-6.

Селезнев, Н.H. [Nikolai N. Seleznyov], Pax Christiana et Pax Islamica: Из истории межнконфессиональныхх связей на средневековом Ближнем Востоке [Pax Christiana et Pax Islamica: On the History of Interconfessional Relations in the Medieval Near East]. (Orientalia et Classica, XLV). Москва: Российский государственный гуманитарный университет, Институт восточных культур и античности, 2014. - 264 pp. - ISBN 978-5-7281-1594-6. 
Селезнев, H.H. [Nikolai N. Seleznyov], “Семь канонов и девять знамений: Вероучительная часть митургической поэмы Йоханнана Бар 3о би Истолкование таин” [“Seven canons and nine signs: Doctrinal part of the liturgical poem of John Bar Zo 'bi Explanation of the Mysteries"], Miscellanea Orientalia Christiana / Russian State University for the Humanities, Institute for Oriental and Classical Studies; Ruhr-Universität Bochum, Seminar für Orientalistik und Islamwissenschaft; ed. by Nikolai N. Seleznyov, Yury N. Arzhanov. Москва: Российский государственный гуманитарный университет, Институт восточных культур и античности, 2014, pр. 92 127. - ISBN 978-5-98604-419-4.

Селезнев, H.H. [Nikolai N. Seleznyov], "Passio secundum Ibn alAkfānī: учение христианских конфессий о крестных страданиях в традиционном арабо-мусульманском религиоведении" ["Passio secundum Ibn al-Akfānī: the doctrine of Christ's Passions on the Cross in the traditional Muslim religious studies"], Miscellanea Orientalia Christiana / Russian State University for the Humanities, Institute for Oriental and Classical Studies; Ruhr-Universität Bochum, Seminar für Orientalistik und Islamwissenschaft; ed. by Nikolai N. Seleznyov, Yury N. Arzhanov. Москва: Российский государственный гуманитарный университет, Институт восточных культур и античности, 2014, pр. 348-358. ISBN 978-5-98604-419-4.

Сеппала, Серафим, свящ. [Serafim Seppälä, Rev.], “Ангелология св. Исаака Сирина" [“Angelology of St Isaac”], Преподобный Исаак Сирин и его духовное наследие. Proceedings of the First International Patristic Conference "Saint Isaac the Syrian and his Spiritual Legacy" (October 10 $10^{\text {th }}-11^{\text {th }}, 2013$, Moscow) / Ss. Cyril and Methodius Theological Institute for Postgraduate Studies; ed. by Alexey R. Fokin, Maksim G. Kalinin, Evgeny A. Pilipenko. Москва: Общецерковная аспирантура и Аокторантура им. свв. Кирилма и Мефодия, 2014, рр. 137161. - ISBN 978-5-9065-4307-3. 
Тамке, M. [Martin Tamcke], “Стремиться понять Исаака Ниневийского и потерпеть неудачу: усилия Густава Биккеля и этика св. Исаака" ["Isaac of Nineveh as a Teacher of Ethics and studying efforts of Gustav Bickell'], Преподобный Исаак Сирин и его духовное наследие. Proceedings of the First International Patristic Conference "Saint Isaac the Syrian and his Spiritual Legacy" (October 10 $10^{\text {th }}-11^{\text {th }}, 2013$, Moscow) / Ss. Cyril and Methodius Theological Institute for Postgraduate Studies; ed. by Alexey R. Fokin, Maksim G. Kalinin, Evgeny A. Pilipenko. Москва: Общецерковная аспирантура и Аокторантура им. свв. Кирилма и Мефодия, 2014, рр. 398 408. - ISBN 978-5-9065-4307-3.

Толстолуженко, М.Ю. [Mikhail Yu. Tolstoluzhenko], “Вот скиния Бога Иакова: прозвище как аргумент в межконфессиональной полемике" [“"Here is the tabernacle of God of Jacob': the nickname as argument in the interdenominational polemics"], Miscellanea Orientalia Christiana / Russian State University for the Humanities, Institute for Oriental and Classical Studies; Ruhr-Universität Bochum, Seminar für Orientalistik und Islamwissenschaft; ed. by Nikolai N. Seleznyov, Yury N. Arzhanov. Москва: Российский государственный гуманитарный университет, Институт восточных культур и античности, 2014, рр. 128-145. ISBN 978-5-98604-419-4.

Трейгер, А.C. [Alexander S. Treiger], "Христология Послания христиан Кипра" ["The Christology of the Letter from the People of Cyprus"], Miscellanea Orientalia Christiana / Russian State University for the Humanities, Institute for Oriental and Classical Studies; Ruhr-Universität Bochum, Seminar für Orientalistik und Islamwissenschaft; ed. by Nikolai N. Seleznyov, Yury N. Arzhanov. Москва: Российский государственный гуманитарный университет, Институт восточных культур и античности, 2014, рр. 311-347. ISBN 978-5-98604-419-4.

Фокин, A.P. [Alexey R. Fokin], “Апокатастасис в сирийской христианской традиции: Евагрий и Исаак” [“Apocatastasis in the Syriac Christian Tradition: Evagrius and Isaac"], 
Преподобньгй Исаак Сирин и его духовное наследие. Proceedings of the First International Patristic Conference "Saint Isaac the

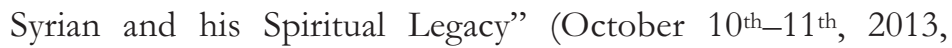
Moscow) / Ss. Cyril and Methodius Theological Institute for Postgraduate Studies; ed. by Alexey R. Fokin, Maksim G. Kalinin, Evgeny A. Pilipenko. Москва: Общецерковная аспирантура и докторантура им. свв. Кирилма и Мефодия, 2014, pp. 173-187. - ISBN 978-5-9065-4307-3.

Фурман, Ю.В. [Yulia V. Furman], “Первый день творения и первые природы в Истории временного мира Йоханнана бар Пенкайе" ["The first day of the Creation and 'the first natures' in the History of the Temporal World of John bar Penkaye"], Miscellanea Orientalia Christiana / Russian State University for the Humanities, Institute for Oriental and Classical Studies; Ruhr-Universität Bochum, Seminar für Orientalistik und Islamwissenschaft; ed. by Nikolai N. Seleznyov, Yury N. Arzhanov. Москва: Российский государственный гуманитарный университет, Институт восточных культур и античности, 2014, pp. 9-25. - ISBN 978-5-98604-419-4.

Фурман, Ю.В. [Yulia V. Furman], "Концепция временного мира у Йоханнана бар Пенкайе и Исаака Сирина" [“The Concept of the Temporal world according to Yohannnān Bar Penkāyē and Isaac the Syrian"], Преподобныгй Исаак Сирин и его духовное Hacsedue. Proceedings of the First International Patristic Conference "Saint Isaac the Syrian and his Spiritual Legacy" (October 10 $0^{\text {th }}-11^{\text {th }}, 2013$, Moscow) / Ss. Cyril and Methodius Theological Institute for Postgraduate Studies; ed. by Alexey R. Fokin, Maksim G. Kalinin, Evgeny A. Pilipenko. Москва: Общецерковная аспирантура и Аокторантура им. свв. Кирилма и Мефодия, 2014, рр. 308-314. - ISBN 978-59065-4307-3.

Фьори, Э. [Emiliano Fiori], “Аионисий Ареопагит и Исаак Сирин: попытка переоценки" ["Dionysius the Areopagite and Isaac: an Attempt at a Reassessment"], Преподобныгй Исаак Сирин и его духовное наследие. Proceedings of the First International Patristic Conference "Saint Isaac the Syrian and 
his Spiritual Legacy" (October 10 $0^{\text {th }}-11^{\text {th }}, 2013$, Moscow) / Ss. Cyril and Methodius Theological Institute for Postgraduate Studies; ed. by Alexey R. Fokin, Maksim G. Kalinin, Evgeny A. Pilipenko. Москва: Общецерковная аспирантура и Аокторантура им. свв. Киримла и Мефодия, 2014, рр. 288 307. - ISBN 978-5-9065-4307-3.

Хагман, П. [Patrik Hagman], “Аскетизм как политическое богословие: подвижник как таинство у св. Исаака Ниневийского” [“The Ascetic as Sacrament: The Ascetical Turn in the Theology of St Isaac of Nineveh"], Преподобныи Исаак Сирин и его духовное наследие. Proceedings of the First International Patristic Conference "Saint Isaac the Syrian and his Spiritual Legacy" (October 10 $10^{\text {th }}-11^{\text {th }}, 2013$, Moscow) / Ss. Cyril and Methodius Theological Institute for Postgraduate Studies; ed. by Alexey R. Fokin, Maksim G. Kalinin, Evgeny A. Pilipenko. Москва: Общецерковная аспирантура и Аокторантура им. свв. Кирилма и Мефодия, 2014, рр. 259273. - ISBN 978-5-9065-4307-3.

Ханерас, C. [Sebastià Janeras], “Некоторые примеры искажения смысла в матинских и новоевропейских переводах творений св. Исаака Сирина” [“Some Examples of Changed Sense in the Latin and Vernacular Versions of Isaac the Syrian"], Преподобныги Исаак Сирин и его духовное наследие. Proceedings of the First International Patristic Conference "Saint Isaac the Syrian and his Spiritual Legacy" (October 10th 11th, 2013, Moscow) / Ss. Cyril and Methodius Theological Institute for Postgraduate Studies; ed. by Alexey R. Fokin, Maksim G. Kalinin, Evgeny A. Pilipenko. Москва: Общецерковная аспирантура и Аокторантура им. свв. Кирилма и Мефодия, 2014, рр. 100-124. - ISBN 978-59065-4307-3.

Хант, А. [Hannah Hunt], "Монах как п^ачущий: преподобный Исаак Сирин и монашеская идентичность в VII столетии и в последующее время" ["The Monk as Mourner: Isaac the Syrian and Monastic Identity in the Seventh Century and Beyond"], Преподобныги Исаак Сирин и его духовное наследие. Proceedings of the First International Patristic Conference 
"Saint Isaac the Syrian and his Spiritual Legacy" (October 10 $10^{\text {th }}$

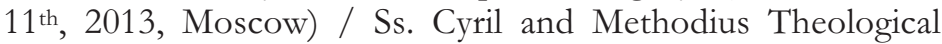
Institute for Postgraduate Studies; ed. by Alexey R. Fokin, Maksim G. Kalinin, Evgeny A. Pilipenko. Москва: Общецерковная аспирантура и Аокторантура им. свв. Кирилла и Мефодия, 2014, рр. 213-224. - ISBN 978-59065-4307-3. 
